\title{
MARKET-TO-BOOK RATIO AND CREATIVE INDUSTRIES - EXAMPLE OF POLISH VIDEO GAMES DEVELOPERS
}

\author{
Rafał Rydzewski ${ }^{1}$ \\ ${ }^{1}$ University of Economics in Katowice, Katowice, Poland, rafal.rydzewski@ue.katowice.pl \\ ORCID: 0000-0003-0562-1167
}

\begin{abstract}
Research purpose. There are many reasons for which a growing interest in research and analysis of video game developers is observed. First, it results from attractive high rates of return on investment in this sector. Second, video games developers, in the author's opinion, constitute a good combination of business and culture which is a ground for development of creative industry. A capital-intensive process of production and the intangibility of video games cause a problem in valuation of developers. Market participants who value future cash flows are in conflict with a historical cost approach used in accounting. This leads to a question of whether the confrontation of these two extreme ways of valuation could be a valuable measure of unrecognised assets for the analysis of video games sector and, as a consequence, of creative industry. The aim of the study is to explore a possible role and use of market-to-book ratio for analysis of this sector.
\end{abstract}

Design/Methodology/Approach. The study starts with a literature review on market-to-book ratio applied to knowledge-based industries. The second part of the research is a comparison of results obtained for 19 biggest listed representatives of the video games sector in Poland to other sectors of Warsaw Stock Exchange. Further analysis juxtaposes the selected Polish representatives with world's biggest ones in this sector. This will allow to draw conclusions about the usefulness of the examined ratio.

Findings. The research shows that the video games sector represents noticeably higher level of market-to book ratio than other industries in Poland and is comparable to the world's representatives. It can be stated that the market's valuation takes into account unrecognised assets (intellectual capital), which are greatly related to possible future cash flows. What is interesting is that, for some of the selected Polish companies, market-to-book ratio keeps decreasing compared to the levels at IPO. This refers to market efficiency in relation to possible speculative bubbles which companies of this sector are often accused of.

Originality/Value/Practical implications. The obtained results are applicable to the investors, analysts and managers of this sector. The research conducted enables a better understanding of the market-to-book ratio as an indicator of economic standing of creative industry companies and its earnings' prediction.

Keywords: Creative industry; Video game sector; Market-to-book ratio; Intellectual capital.

JEL codes: M40; G10.

\section{Introduction}

There are many reasons for which a growing interest in research and analysis of video game developers is observed. One reason is a consequence of global economy trends on which this sector arises. First to mention is the phenomenon of digitalization of human activities. The word digitalization refers to a process of adopting digital technology in social and business contexts to create a value in a new way. It can be conflated with servitization. The often-used interchange term digitization is a process of converting analog signals into digital form. It refers to a technical process of dematerialization of information (Gobble, 2018; Legner et al., 2017).

New generations are brought up in a digital landscape of day-to-day activities with an access to unlimited data. Technologies such as social media and big data are considered to have a core role in contemporary business models with a positive impact on business performance (Bouwman, Nikou, Molina-Castillo, \& de Reuver, 2018). In this digital environment, the entertainment industry seems to be particularly interesting. Video games developers, as one of the representatives of this industry, benefit from the intangible - digital - character of the product. It allows for almost instant delivery to the customer and, as a consequence, extremely low distribution costs which are reflected in the financial situation of the 
entities. The second trend is the development of the creative sector, to which video game developers belong. Its growth is observed worldwide and it significantly contributes to a gross domestic product, export, growth and sustainable development (Jones, Comfort, Eastwood, \& Hillier, 2004; UNCTAD, 2018). The size of knowledge economy reflected by contribution of creative goods and services enhances a level of economic development and competitiveness of economies (Boccella \& Salerno, 2016; Gouvea \& Vora, 2018). Creative industry such as video games developers questions a common opinion that art in general cannot be a good business. Financial results and forecasts of this sector are interesting especially for investors. According to the Newzoo report, a consumer spend on games will grow with a compound annual growth rate (CAGR) of +10.3 percent between 2017 and 2021 and the 10-year CAGR for the market (2012-2021) at +11.0percent (Wijman, 2018). These two-digit numbers may seem already impressive; however, a quick look at a 5-year growth of market capitalisation of the biggest representatives of this sector shows more spectacular results: Activision Blizzard, Inc. +126 percent; Electronic Arts Inc. +235 percent; Take-Two Interactive Software +229 percent.

The attractive rates of growth, capital-intensive process of production, intangibility of product and its means of production (well-educated employees) make it a challenging ground for financial analysts and investors. They require new methods and approach for valuation and assessing the financial situation of this sector (Torchała, 2017). Video games sector, as a part of creative industry, is driven by innovation, human creativity, skills and talent. It is a carrier of symbolic messages for consumers and is a subject of an intellectual property (Klimas \& Czakon, 2018; UNCTAD, 2010). These characteristics are imponderable in financial statements (Niemczyk, 2015) and result in a specific structure of assets and sources of financing. Existence of unreported, intangible assets has an impact on abnormal levels of earnings. As a consequence, this influences equity valuation especially by generation of higher levels of future earnings (Kohlbeck \& Warfield, 2007). Existing methods of analysis do not incorporate these characteristics. An importance of this remark can be debatable because the market focuses on a valuation of future - not past and current situation reported in statement. Investors estimate future cash flow based on knowledge of a developer and success of the product, which is in strong conflict with the historical cost approach used in accounting. Nonetheless, it can lead to a question of whether the confrontation of these two extreme ways of valuation - market value and book value - could be a valuable measure for the analysis of video games sector and, as a consequence, of creative industry. The aim of the study is to explore a possible role and use of market-to-book ratio for analysis of this sector. This will allow practitioners a better understanding of the popular indicator and the dependencies in sectors which are driven by creativity and knowledge. Results will also broader the knowledge on the specificity of this sector.

For the purpose of this paper some Polish video games developers have been chosen. In the region of Central and Eastern Europe, game development is on the rise and Poland and other countries are enhancing their technological competitiveness (UNCTAD, 2018, p. 10). According to the United Nations Conference on Trade and Development's (UNCTAD) report, Poland is in 8th place in the top 20 creative goods exporters defined as a developed country, behind the United States, France, Italy, United Kingdom, Germany, Switzerland and the Netherlands. Moreover, statistics for developing countries place Poland in seventh position behind China, Hong Kong (China), India, Singapore, Taiwan Province of China and Turkey (UNCTAD, 2018, p. 21). This shows a potential of this country in the creative industry and places Poland on a leader's position in its region. According to a report 'The State of Polish Video Games Sector 2017', the Polish video games sector is 23th biggest market in the world (by the total game revenues). The population of enterprises operating in this sector in Poland is estimated at 330 entities. Most of them are micro enterprises but there are enough companies listed to make a valuable research. Moreover, video games companies have a high share in IPOs on the Polish stock market. In the period from 2016 to 2018 they constituted 10 percent of all IPOs on the WSE Regulated Market and 24 percent on an alternative market - NewConnect. Moreover, according to the 'State of Polish Video Games Industry 2017', the size of Polish video games market is expected to rise by about 20 percent in the period from 2016 to 2019 (State of Polish Video Games Industry 2017, 2017). The results of three sample companies - CD Projekt Red +986 percent; The Farm $51+210$ percent; 11 bit studios +2300 percent (sic!) - may also look impressive. This stresses the importance of scientific research on methods of valuation. Last but not least is the simplicity of most entities operating in this industry. As Polish video games sector is in its early stage of development, it mostly consists of video 
game producers and is not engaged in other sectors. This makes Poland an interesting case to be studied in reference to the aim of this study.

\section{Literature Review}

\section{Creative industry}

Defining creative industry is very context-dependent but the core of all leads to a definition of a part of economy characterized by the 'input of creative individuals' (Innerhofer, Pechlaner, \& Borin, 2018, p. 2 ) or, broader, as an industry in which 'creativity is an input and content or intellectual property is the output' (Potts \& Cunningham, 2008). All approaches to defining the creative industry show that it is not homogeneous. A popular approach of Department for Culture, Media and Sport in the United Kingdom focuses both on more 'tangible results' of creativity such as crafts or architecture and industries with an intangible character of a product, for example, film, music, video games (DCMS, 1998, 2001). Other approaches such as cultural concentric circles model emphasise a core role of culture which is a centre of the creative process. This gives primacy of artistic creativity in the process (Carvalho \& Cruz, 2017; Throsby, 2008). Despite the confusion, in a clear definition, creative industry can be generally described as a mix of creativity, culture and business. This brings new challenges to management and finance of entities of creative industries.

Challenges in management are placed around tensions between work ethos and practices in both creative and more routinised activities. Managers have to apply management methods to balance the advantages of tight integration and flexibility of the organization. On the other hand, employees engaged in creative processes are encouraged to develop deep work ability to produce a real value and to drive oneself to intrinsic forms of motivation (Newport, 2016). In this context the interest in agile methods that are commonly used in reference to, for example, complex software development is justified. Unlike creativity, the methods have no mechanism for maintenance (Rehman, Maqbool, Riaz, Qamar, \& Abbas, 2018). Agile methods such as Scrum and Kanban face problems of changes in requirements; they allow workers to self-organize the teams and are transparent to everyone. These constitute a constant feedback which is crucial for the quality of a deliverable product (Lei, Ganjeizadeh, Jayachandran, \& Ozcan, 2017).

The characteristic of creative industry is reflected in a company's financial situation. Accounting is a main 'language' of finance and its outcome is a financial statement, which provides synthetic information on the past and present situation of the company. A scope of this report is defined by law, standards of accounting and accounting policies to protect the interests of the owners. As the innovation activities have a positive impact on companies' performance, it is an important area of interest for a user (Piotrowska, 2016). Because no direct numbers can be given, there is a problem in financial reporting of creative businesses. Creativity of individuals is a main asset and a source of value; however, it is not directly reflected on a balance sheet. One can find possible ways of changing this situation by integrated reporting or supplementing an additional item on the balance sheet (Piotrowska, 2016). Nevertheless, there is no commonly accepted form for disclosure of creativity, knowledge and other characteristics of modern economy, mostly because of problems with the reliability of calculations. Still, creativity and knowledge capital are imponderable and create a gap in financial reporting (Niemczyk, 2015; Wyatt \& Abernethy, 2008).

\section{Market-to-Book ratio}

Creativity and knowledge are a source of competitive advantage in the global environment. Firms are usually dependent on financial measures which are insufficient to capture this advantage. Limitations of firm performance measures based on financial data are widely discussed in literature and as a result of this, the approach of balance scorecard has been developed. Data collected with the use of accounting do not fully reflect the company's value. The other factor is market capitalisation. The price of share of the company is assumed to be 'equal to the present value of the expected future dividend' (Penman, 1996, p. 237). Comparison of this book value of the firm and its market capitalization creates marketto-book indicator. It is also called a price-to-book ratio $(P / \mathrm{BV})$. First, this relation places the market valuation in a numerator. This represents the attitude to valuation which is based on a future cash flow and methods such as discounted cash flow model. A reason for selecting the market price is that it 
includes all information and factors available in the market. It refers to the efficient market hypothesis which states that securities markets are efficient in reflecting immediately all available information about individual stocks and a whole market. News by its character is unpredictable and thus 'price changes must be unpredictable and random' (Malkiel, 2003, p. 59). Of course, considering a current state of research, this assumption is debatable and judgement of investors is sometimes wrong which leads to inefficiency (Penman, 1996, pp. 256-257). Behavioural biases influence the market prices (Singh \& Shivaprasad, 2018) and 'predictable patterns in stock returns can appear over time and even persist for short periods' (Malkiel, 2003, p. 80).

Second, in the above-mentioned relation, in the denominator there is the book value, which is assets less total debt of the company. It is equal to shareholders' equity. It represents the value of the company calculated with the use of accounting principles. In addition to information about the company's equity, the book value is in relation to stock price movement (Francis \& Schipper, 1999). This allows to compare values with each other because they are mutually dependent.

Market-to-book ratio is often compared with the price-earnings ratio $(P / E)$, which received more academic attention in the past. The works of Fama and French on efficient market document that marketto-book ratio 'explains mean stock returns, accompanied by conjectures that is a proxy for risk or an indicator of distress, the difference between market and book leverage, or a mispriced stocks' (Penman, 1996, p. 235). Both measures - price-earnings and market-to-book - are products of the accounting applied. Accounting rules determine the earnings and book value but do not influence the market price. The models which combine these two measures are explored with promising results (Cheng \& McNamara, 2000) because the difference between book value in earnings can add value to prediction (e.g. dividends have an influence on book value but not on earnings (Ohlson, 1995)).

Interpretation of market-to-book ratio can be summarised as follows (Cheng \& McNamara, 2000, p. 350; Fama \& French, 1992; Penman, 1996, pp. 235-236):

- It is an indicator of expected return on equity.

- It is growth indicator (ROE is a surrogate of growth).

- It is determined by leverage of the company.

- It reflects the production efficiency of a firm.

- It can also explain variation in average returns.

The $\mathrm{P} / \mathrm{BV}$ ratio base value is 1 . This applies when the 'book value is sufficient for all information about future earnings, and thus for price'. When the ratio departs from base value this means that other information has influenced the projection of future earnings (Penman, 1996, pp. 242-243).

Current earnings may fluctuate around their expected value. Because the market-to-book ratio can be interpreted as earnings growth indicator, its main advantage is that it is not affected by the volatility of the company's results. It reflects profitability expected by market participants. This stays in opposition to the mentioned price-earnings ratio which indicates future earnings growth (Penman, 1996, pp. 256257; Shroff, 1995, pp. 53). Therefore, market-to-book ratio can be a valuable measure for market participants who, by becoming shareholders, possess the book value of the company.

\section{Applying of Market-to-Book ratio to creative industry analysis}

Creative industry works with the use of assets that are imponderable for financial statements. Creativity and intellectual capital are considered to be a 'significant hidden value' and it may result in a difference between book and market value of companies (Forte, Tucker, Matonti, \& Nicolo, 2017). The difference can determine and measure the unrecognised value because it is the price which the market participants pay for the unreported assets.

Range of this hidden value in creative industry is far bigger than just know-how and information on future sales. It can be knowledge, brand or others. Just to mention some video games developers and other digital entertainment services providers such as YouTube, Netflix, Facebook - these companies also benefit from an immersive experience of their products (losing time perception while using) (Michailidis, Balaguer-Ballester, \& He, 2018; Sharma, Mehra, Kaulgud, \& Podder, 2018). Also, as the 
offered products involve pleasurable activity they can lead to habits or even addictions (Boyle, Connolly, Hainey, \& Boyle, 2012). This situation can be priced by the market as well.

As the literature review shows that there is a possibility of existence of unrecognised assets, it seems reasonable to ask the following research question:

RQ: Does the relation of the market capitalisation and book value of creative industry representatives show the existence of unrecognised assets?

In order to answer this research question and to achieve the aim of this study with regard to the Polish video game developer sector, the following hypotheses are set:

H1: Polish representatives of video games developers are characterized by higher values of the market-to-book ratio in reference to Warsaw Stock Exchange indexes.

H2: The world representatives of this sector are characterized by a similar relationship of market capitalisation and book value to Polish representatives.

\section{Methodology}

Testing of the presented hypotheses is designed as a two-step process. First, the research is based on a comparison of results obtained for selected representatives of video games sector in Poland and the results of other sectors of Warsaw Stock Exchange. Second, the analysis juxtaposes the Polish representatives with world's biggest ones of this sector. This allows to draw conclusions about the usefulness of the examined ratio, test hypotheses and answer the research question.

\section{Research sample}

For the selection of Polish video game developers the Forbes report, 'The biggest game producers. Polish video games sector in 2018', has been used. Table 1 shows the biggest representatives with value greater than 5 million USD (currency rates used on the date of publication of Forbes report and obtained from the National Bank of Poland's website). The spread between first and last representatives in the table shows a huge domination of a few entities on this market. Worth to mention is that only one company presented in the table, Techland, is not listed. Therefore it is not included in further study. One More Level has operated in a different sector until 2017 and has been included for control purposes. If game developers had their own level of market-to-book ratio, this company would have different results. Considering an initial stage of the study and an early stage of development of this sector in Poland, it seems to be justified to limit research sample to its largest representatives. There are eight companies listed on Warsaw Stock Exchange in April 2019 which are not included in this study. Their market value on 30 April 2019 was 276 million PLN (64 million EUR; 72 million USD). However, only two of them have been listed before the selected companies in Table 1, which does not allow to obtain a sufficient number of observations.

Table 1. Biggest representatives of Polish video games developers (Source: author's compilation on the basis of Forbes report 'The biggest game producers. Polish video games sector in 2018' and https://www.nbp.pl/)

\begin{tabular}{|c|l|c|c|c|}
\hline No. & \multicolumn{1}{|c|}{ Name } & $\begin{array}{c}\text { Value (million } \\
\text { PLN) }\end{array}$ & $\begin{array}{c}\text { Value (million } \\
\text { USD)* }\end{array}$ & $\begin{array}{c}\text { Value (million } \\
\text { EUR)* }\end{array}$ \\
\hline 1 & CD PROJEKT & 18974.1 & 5179.9 & 4429.5 \\
\hline 2 & TECHLAND & 3527.0 & 962.9 & 823.4 \\
\hline 3 & 11 BIT STUDIOS & 1100.1 & 300.3 & 256.8 \\
\hline 4 & PLAYWAY & 805.2 & 219.8 & 188.0 \\
\hline 5 & TEN SQUARE GAMES & 620.6 & 169.4 & 144.9 \\
\hline 6 & FARM 51 & 178.2 & 48.6 & 41.6 \\
\hline 7 & CHERRYPICK & 136.6 & 37.3 & 31.9 \\
\hline 8 & CI GAMES & 131.5 & 35.9 & 30.7 \\
\hline 9 & VIVID GAMES & 115.1 & 31.4 & 26.9 \\
\hline 10 & CREATIVEFORGE & 114.7 & 31.3 & 26.8 \\
\hline 11 & BLOOBER TEAM & 84.5 & 23.1 & 19.7 \\
\hline 12 & ONE MORE LEVEL & 78.1 & 21.3 & 18.2 \\
\hline
\end{tabular}




\begin{tabular}{|c|l|c|c|c|}
\hline 13 & ARTIFEX MUNDI & 73.5 & 20.1 & 17.2 \\
\hline 14 & T-BULL & 69.1 & 18.9 & 16.1 \\
\hline 15 & ULTIMATE GAMES & 39.5 & 10.8 & 9.2 \\
\hline 16 & FOREVER ENTERTAINMENT & 35.9 & 9.8 & 8.4 \\
\hline 17 & IFUN4ALL & 35.1 & 9.6 & 8.2 \\
\hline 18 & JUJUBEE & 32.8 & 9.0 & 7.7 \\
\hline 19 & VARSAV GAME STUDIOS & 29.8 & 8.1 & 7.0 \\
\hline 20 & FAT DOG GAMES & 27.5 & 7.5 & 6.4 \\
\hline 21 & 7 LEVELS & 27.5 & 7.5 & 6.4 \\
\hline
\end{tabular}

*Calculation on the basis of currency rates: EUR/PLN 4.2836 and USD/PLN 3.6684

Selection of a research sample for world video games developers is problematic due to availability of data and developed stage of this sector. Most of the representatives not only operate as a video game developer but have a broader scope of activities. For this reason the author has selected the biggest representatives of world game developers (presented in Table 2). The companies from 1 to 3 are mainly game developers and the companies from 4 to 6 work with a use of similar assets and are also present in the video game developer industry. This selection allows to check the existence of unrecognised asset of Polish representatives in relation to world developers and capital groups involved in this sector.

Table 2. Selected representatives of world video games developers and their market capitalisation (Source: author's compilation on the basis of Newzoo reports and macrotrends.net)

\begin{tabular}{|c|l|c|c|c|}
\hline No. & \multicolumn{1}{|c|}{ Name } & $\begin{array}{c}\text { Value (billion } \\
\text { PLN)* }\end{array}$ & $\begin{array}{c}\text { Value (billion } \\
\text { USD) }\end{array}$ & $\begin{array}{c}\text { Value (billion } \\
\text { EUR)* }\end{array}$ \\
\hline 1 & ACTIVISION BLIZZARD & 205.8 & 56.1 & 48.0 \\
\hline 2 & ELECTRONIC ARTS & 142.2 & 38.8 & 33.2 \\
\hline 3 & TAKE-TWO INTERACTIVE & 48.1 & 13.1 & 11.2 \\
\hline 4 & APPLE & 3451.2 & 940.8 & 805.7 \\
\hline 5 & ALPHABET (owner of GOOGLE) & 3359.2 & 915.7 & 784.2 \\
\hline 6 & MICROSOFT CORPORATION & 2964.4 & 808.1 & 692.0 \\
\hline
\end{tabular}

* Calculation on the basis of currency rates: EUR/PLN 4.2836 and USD/PLN 3.6684

\section{Market-to-Book ratio data collection and calculations}

Because of the popularity of the market-to-book ratio (MTB), own calculations are abandoned on account of bigger range of data analysis. Data have been obtained from Stooq finance data service (Stooq) for Polish video games representatives and Macrotrends portal (Macrotrends) for the world representatives. All ratios obtained are calculated with use of the following formula:

$$
\mathrm{MTB}=\frac{P}{\text { BVPS }}=\frac{\text { MCap }}{\text { BV }}
$$

where

$P$ is the share price,

BVPS is the book value per share,

MCap is market capitalisation and

$\mathrm{BV}$ is the book value of the company.

The data used are monthly market-to-book indicators for Polish stock market and quarterly data for world representatives. The choice is dictated by the availability of data and avoiding high volatility of results related to the volatility of market capitalization of entities. This choice of data offers limited possibility to fully compare the results of the Polish and global sectors; however, in the opinion of the author, it does not affect the final outcomes of this early stage of research. The range of data constitutes all ratios available since 2007. 


\section{Results}

Calculation of main statistics of market-to-book ratio is presented in Table 3. As expected, in most cases, high level of examined ratio is observed. The median for Polish video game developers is higher than 5 in more than 70 percent of them. Three biggest representatives (bold in the table) are a part of this group. This shows that the market participants pay five times more for equity of the company. One More Level as a 'control' example has ratio with clearly lower level in reference to other examples and with the lowest coefficient of variation.

The comparison of this result to the main statistics of market-to-book ratios of Warsaw Stock Exchange indexes (Table 4) shows that game developers are characterized by noticeably higher values. The index WIG-MOTO, which groups companies of the automotive industry, is the only one that exceeds the mean and median value of 2 . On that basis it can be clearly seen that for video game developers there is a market surplus of valuation in relation to other sectors. The results prove the existence of unrecognised assets. It seems to be justified to claim that other information than obtained from financial reporting has influenced the valuation done by market participants.

Table 3. The main statistics for all available data from 2007 to February 2018 for Polish game developers (Source: author's compilation on the basis of obtained data)

\begin{tabular}{|l|r|r|r|r|r|r|}
\hline Name & Min. & Max. & Mean & Median & $\begin{array}{r}\text { Standard } \\
\text { deviation }\end{array}$ & $\begin{array}{c}\text { Coefficient } \\
\text { of variation }\end{array}$ \\
\hline 7 LEVELS & 7.5 & 14.2 & 11.8 & 11.7 & 1.9 & $16 \%$ \\
\hline $\mathbf{1 1}$ BIT STUDIOS & $\mathbf{2 . 6}$ & $\mathbf{2 3 . 4}$ & $\mathbf{8 . 2}$ & $\mathbf{7 . 3}$ & $\mathbf{5 . 1}$ & $\mathbf{6 2 \%}$ \\
\hline ARTIFEX MUNDI & 1.2 & 8.7 & 3.8 & 2.4 & 2.6 & $70 \%$ \\
\hline BLOOBER TEAM & 0.8 & 15.3 & 3.9 & 3.3 & 2.6 & $67 \%$ \\
\hline CD PROJEKT & $\mathbf{2 . 8}$ & $\mathbf{7 3 . 3}$ & $\mathbf{1 0 . 0}$ & $\mathbf{8 . 3}$ & $\mathbf{9 . 3}$ & $\mathbf{9 3 \%}$ \\
\hline CREATIVEFORGE & 3.2 & 14.1 & 6.9 & 5.0 & 3.9 & $57 \%$ \\
\hline CHERRYPICK & 4.2 & 32.3 & 15.1 & 11.5 & 9.6 & $64 \%$ \\
\hline CI GAMES & 1.2 & 10.8 & 3.8 & 2.9 & 2.5 & $66 \%$ \\
\hline FARM 51 & 3.2 & 24.8 & 7.8 & 6.3 & 4.3 & $55 \%$ \\
\hline FAT DOG GAMES & 0.1 & 13.7 & 1.0 & 0.3 & 1.9 & $182 \%$ \\
\hline IFUN4ALL & 5.6 & 17.3 & 8.5 & 7.5 & 3.0 & $35 \%$ \\
\hline JUJUBEE & 4.2 & 59.5 & 24.2 & 17.3 & 14.8 & $61 \%$ \\
\hline ONE MORE LEVEL & 1.8 & 3.0 & 2.3 & 2.3 & 0.3 & $15 \%$ \\
\hline PLAYWAY & $\mathbf{6 . 9}$ & $\mathbf{2 1 . 8}$ & $\mathbf{1 1 . 5}$ & $\mathbf{1 0 . 1}$ & $\mathbf{4 . 4}$ & $\mathbf{3 8 \%}$ \\
\hline T-BULL & 2.2 & 35.5 & 14.4 & 10.1 & 10.8 & $75 \%$ \\
\hline TEN SQUARE GAMES & 20.6 & 71.1 & 36.5 & 34.8 & 16.5 & $45 \%$ \\
\hline ULTIMATE GAMES & 18.3 & 28.5 & 23.4 & 22.4 & 4.1 & $18 \%$ \\
\hline VARSAV GAME STUDIOS & 1.1 & 21.8 & 5.1 & 3.3 & 4.0 & $79 \%$ \\
\hline VIVID GAMES & 2.0 & 18.6 & 7.8 & 5.6 & 5.0 & $65 \%$ \\
\hline FOREVER ENTERTAINMENT & 0.8 & 58.2 & 8.0 & 4.8 & 9.5 & $118 \%$ \\
\hline
\end{tabular}


Table 4. The main statistics for all available data from 2007 to February 2018 for Warsaw Stock Exchange indexes (Source: author's compilation on the basis of obtained data)

\begin{tabular}{|l|r|r|r|r|r|r|}
\hline Name & \multicolumn{1}{|c|}{ Min. } & \multicolumn{1}{c|}{ Max. } & \multicolumn{1}{c|}{ Mean } & Median & $\begin{array}{c}\text { Standard } \\
\text { deviation }\end{array}$ & $\begin{array}{c}\text { Coefficient } \\
\text { of variation }\end{array}$ \\
\hline WIG & 0.72 & 3.55 & 1.24 & 1.20 & 0.34 & $28 \%$ \\
\hline WIG20 & 0.90 & 3.75 & 1.47 & 1.40 & 0.36 & $25 \%$ \\
\hline WIG-TELKOM & 0.55 & 2.16 & 1.08 & 0.97 & 0.36 & $33 \%$ \\
\hline WIG-SPOZYW & 0.42 & 2.61 & 0.98 & 0.91 & 0.29 & $30 \%$ \\
\hline WIG-PALIWA & 0.39 & 2.57 & 1.04 & 0.91 & 0.44 & $43 \%$ \\
\hline WIG-ODZIEZ & 0.89 & 1.62 & 1.33 & 1.32 & 0.21 & $15 \%$ \\
\hline WIG-NRCHOM & 0.33 & 4.80 & 0.75 & 0.64 & 0.50 & $67 \%$ \\
\hline WIG-MOTO & 1.52 & 2.60 & 2.12 & 2.13 & 0.37 & $17 \%$ \\
\hline WIG-MEDIA & 1.01 & 3.83 & 1.66 & 1.45 & 0.56 & $34 \%$ \\
\hline WIG-LEKI & 1.06 & 3.43 & 1.58 & 1.40 & 0.56 & $36 \%$ \\
\hline WIG-INFO & 0.61 & 3.11 & 1.43 & 1.48 & 0.38 & $27 \%$ \\
\hline WIG-GORNIC & 0.41 & 4.98 & 1.22 & 1.22 & 0.70 & $58 \%$ \\
\hline WIG-ENERG & 0.51 & 1.87 & 0.89 & 0.84 & 0.32 & $36 \%$ \\
\hline WIG-CHEMIA & 0.34 & 2.15 & 1.39 & 1.45 & 0.48 & $34 \%$ \\
\hline WIG-BUDOW & 0.51 & 6.03 & 1.23 & 0.95 & 0.81 & $66 \%$ \\
\hline WIG-BANKI & 0.69 & 4.26 & 1.24 & 1.02 & 0.55 & $44 \%$ \\
\hline
\end{tabular}

An inquisitive analyst can say that this sector is currently in the 'bubble phase'. However, for some of the selected Polish game developers, market-to-book ratio keeps decreasing compared to the levels at IPO (Fig. 1). Indeed, euphoric mood at IPO can be observed and may be subject to further research; nevertheless, verification of these high levels by the market may indicate a certain level of its efficiency.

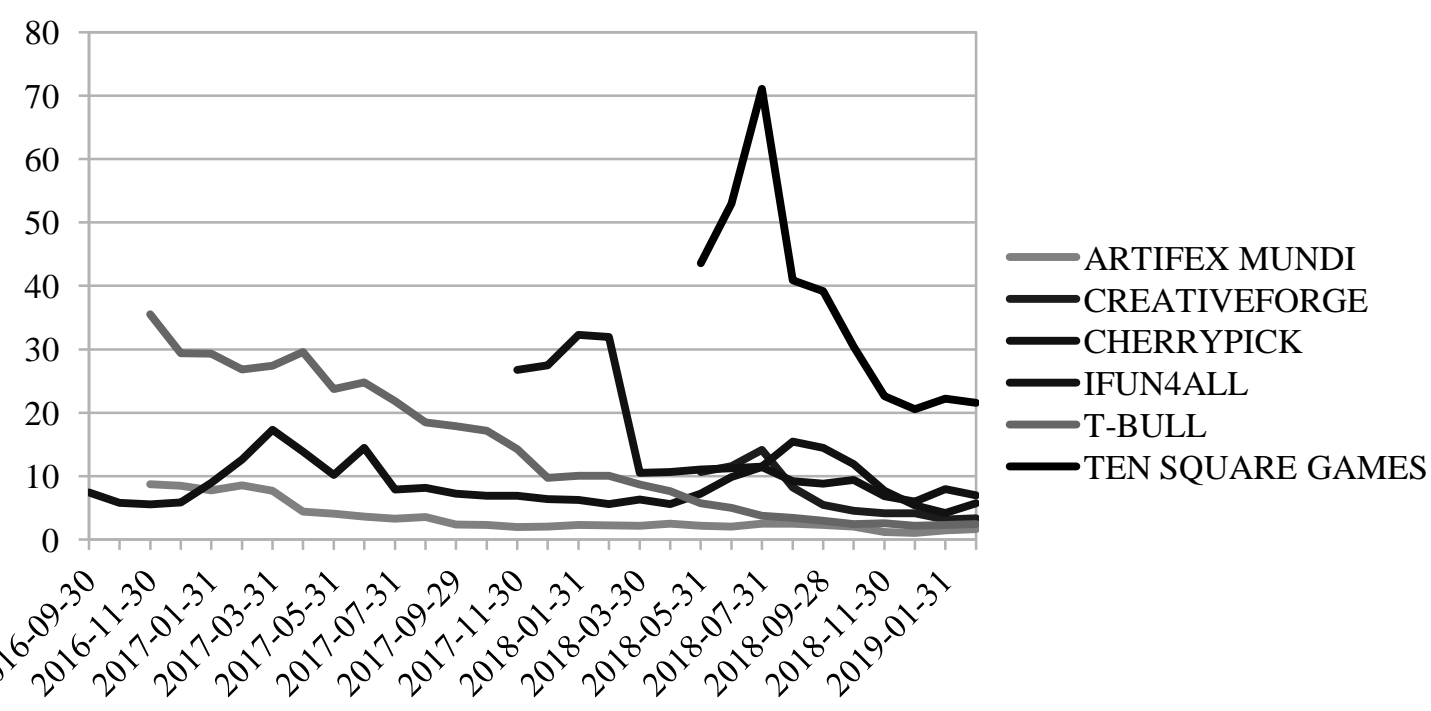

Fig. 1. Market-to-book ratio of selected Polish game developers (Source: author's compilation on the basis of obtained data) 
The second phase of the research juxtaposes the Polish representatives with the world's biggest ones of this sector. The main statistics of selected world representatives (Table 5) also represent higher levels of market-to-book ratio; however, they are more toned down. The three game developer representatives have still a relatively high level of coefficient of variation but mean and median are lower than for the three biggest representatives on the Polish market. Nevertheless, the three popular world companies involved in knowledge-intensive activities (Apple, Alphabet and Microsoft) represent the statistics of mean and median around 4 and 5.

Table 5. The main statistics for all available data from 2007 to February 2018 for selected world representatives (Source: author's compilation on the basis of obtained data)

\begin{tabular}{|l|r|r|r|r|r|r|}
\hline Name & Min. & Max. & Mean & Median & $\begin{array}{c}\text { Standard } \\
\text { deviation }\end{array}$ & $\begin{array}{c}\text { Coefficient } \\
\text { of variation }\end{array}$ \\
\hline ACTIVISION BLIZZARD & 0.9 & 6.0 & 2.5 & 2.1 & 1.4 & $58.2 \%$ \\
\hline ELECTRONIC ARTS & 1.5 & 8.3 & 4.3 & 3.7 & 2.1 & $49.3 \%$ \\
\hline TAKE-TWO INTERACTIVE & 1.0 & 9.0 & 3.7 & 2.7 & 2.2 & $60.0 \%$ \\
\hline APPLE & 2.6 & 10.0 & 5.0 & 4.7 & 1.5 & $30.7 \%$ \\
\hline ALPHABET & 2.9 & 9.6 & 4.4 & 4.1 & 1.4 & $31.8 \%$ \\
\hline MICROSOFT CORPORATION & 2.7 & 10.2 & 5.0 & 4.3 & 2.0 & $39.6 \%$ \\
\hline
\end{tabular}

These results do not provide a strong ground for comparison of Polish and world sectors but, again, they show the existence of unrecognised assets which are valued by the market. The noticeably lower results of the world representatives can be a starting point for further analysis of the Polish market to examine whether it is overvalued.

\section{Conclusions}

The conducted research has allowed to obtain an answer to the research question: Does the relation of the market capitalisation and book value of creative industry representatives show the existence of unrecognised assets?

Verification of the first hypothesis shows that Polish representatives of video games developers are characterized by higher values of the market-to-book ratio in reference to Warsaw Stock Exchange indexes. The median of market-to-book ratio for Polish video game developers is higher than 5 in case of more than $70 \%$ of them. Verification of the second hypothesis does not give a clear answer. Comparison of Polish and world representatives shows only that the game developers represent noticeably higher level of market-to book ratio than other industries. Polish representatives present larger coefficient of variation levels and, frequently, very high values of the examined ratio. The world's biggest representatives are more stable in their market-to-book ratio results. Polish game developers sector can be compared to the world's representatives but this relation requires further study.

However, the research has some limitations such as availability of data which affects the reliability of results. Comparability of results is also limited by the fact that the companies use different business models. Moreover, the research has an exploring character and does not fully explain the relations. To summarize, it can be stated that the market's valuation takes into account unrecognised assets (intellectual capital), which are greatly related to possible future cash flows. The results show the existence of unreported assets that influence the future earnings of the companies of this sector. Such a valuation can be practically applied to assessment of size of competencies and intellectual capital present in the companies and already valued by the market participants.

Furthermore, results may allow academic researchers, practitioners and managers to better understand the market-to-book ratio of video game developer sector and of other sectors of creative industries. It proves that analysts have to also take into account non-accounting sources of information because they impact the market value significantly more in this sector. 
Finally, the research shows there is a ground for further statistical analysis of market-to-book and other financial measures. Similar and broader studies may also be applied to other creative industries. Further analysis may be conducted in reference to valuation of this sector. It would be needed to broader the statistical analysis and research sample including other capital market ratios (e.g. price-earnings ratio). It is worth conducting a study which investigates the market reaction to information about the company and its products in reference to creative activities which are not mandatory in financial statements. Taking into account the availability of data, video games developers are an interesting case of creative industry on the public stock market.

\section{References}

Boccella, N., \& Salerno, I. (2016). Creative economy, cultural industries and local development. Procedia-Social and Behavioral Sciences, 223, 291-296.

Bouwman, H., Nikou, S., Molina-Castillo, F. J., \& de Reuver, M. (2018). The impact of digitalization on business models. Digital Policy, Regulation and Governance, 20(2), 105-124.

Boyle, E. A., Connolly, T. M., Hainey, T., \& Boyle, J. M. (2012). Engagement in digital entertainment games: A systematic review. Computers in Human Behavior, 28(3), 771-780.

Carvalho, L., \& Cruz, S. C. S. (2017). Creative industries in Brazil: on the measurement of their size and relative importance. Creative Industries Journal, 10(3), 238-257.

Cheng, C. S. A., \& McNamara, R. (2000). The valuation accuracy of the price-earnings and price-book benchmark valuation methods. Review of Quantitative Finance and Accounting, 15(4), 349-370.

DCMS. (1998). Creative Industries Mapping Document 1998. Retrieved from http://webarchive.nationalarchives.gov.uk/+/http://www.culture.gov.uk/reference_library/publications/4740.aspx

DCMS. (2001). Creative Industries Mapping Document 2001. Retrieved from http://webarchive.nationalarchives.gov.uk/+/http://www.culture.gov.uk/reference_library/publications/4632.aspx

Fama, E. F., \& French, K. R. (1992). The cross-section of expected stock returns. The Journal of Finance, 47(2), $427-465$.

Forte, W., Tucker, J., Matonti, G., \& Nicolo, G. (2017). Measuring the intellectual capital of Italian listed companies. Journal of Intellectual Capital, 18(4), 710-732.

Francis, J., \& Schipper, K. (1999). Have financial statements lost their relevance? Journal of Accounting Research, 37(2), 319-352.

Gobble, M. M. (2018). Digitalization, Digitization, and Innovation. Research-Technology Management, 61(4), 56-59.

Gouvea, R., \& Vora, G. (2018). Creative industries and economic growth: stability of creative products exports earnings. Creative Industries Journal, 11(1), 22-53. https://doi.org/10.1080/17510694.2017.1416529

Innerhofer, E., Pechlaner, H., \& Borin, E. (2018). Entrepreneurship in Culture and Creative Industries. Springer.

Jones, P., Comfort, D., Eastwood, I., \& Hillier, D. (2004). Creative industries: economic contributions, management challenges and support initiatives. Management Research News, 27(11/12), 134-145.

Klimas, P., \& Czakon, W. (2018). Organizational innovativeness and coopetition: a study of video game developers. Review of Managerial Science, 12(2), 469-497. https://doi.org/10.1007/s11846-017-0269-5

Kohlbeck, M., \& Warfield, T. D. (2007). Unrecorded intangible assets: Abnormal earnings and valuation. Accounting Horizons, 21(1), 23-41

Legner, C., Eymann, T., Hess, T., Matt, C., Böhmann, T., Drews, P., Ahlemann, F. (2017). Digitalization: opportunity and challenge for the business and information systems engineering community. Business \& Information Systems Engineering, 59(4), 301-308.

Lei, H., Ganjeizadeh, F., Jayachandran, P. K., \& Ozcan, P. (2017). A statistical analysis of the effects of Scrum and Kanban on software development projects. Robotics and Computer-Integrated Manufacturing, 43, 59-67.

Macrotrends.net [Accessed 31.03.2015]. Available from Internet: https://www.macrotrends.net/ 
Malkiel, B. G. (2003). The efficient market hypothesis and its critics. Journal of Economic Perspectives, 17(1), 59-82.

Michailidis, L., Balaguer-Ballester, E., \& He, X. (2018). Flow and immersion in video games: The aftermath of a conceptual challenge. Frontiers in Psychology, 9.

Newport, C. (2016). Deep work: Rules for focused success in a distracted world. Hachette UK.

Niemczyk, L. (2015). Kapitat intelektualny w księgach rachunkowych oraz sprawozdawczości przedsiębiorstwa (Wydanie 1). Rzeszów: Wydawnictwo Uniwersytetu Rzeszowskiego.

Ohlson, J. A. (1995). Earnings, book values, and dividends in equity valuation. Contemporary Accounting Research, 11(2), 661-687.

Penman, S. H. (1996). The articulation of price-earnings ratios and market-to-book ratios and the evaluation of growth. Journal of Accounting Research, 34(2), 235-259. https://doi.org/10.2307/2491501

Piotrowska, K. (2016). Innovation in financial statements--evolution and trends. Contemporary Challenges for Accounting in a Global Environment, 139.

Potts, J., \& Cunningham, S. (2008). Four models of the creative industries. International Journal of Cultural Policy, 14(3), 233-247.

Rehman, F. ur, Maqbool, B., Riaz, M. Q., Qamar, U., \& Abbas, M. (2018). Scrum Software Maintenance Model: Efficient Software Maintenance in Agile Methodology. In 2018 21st Saudi Computer Society National Computer Conference (NCC) (pp. 1-5). https://doi.org/10.1109/ncg.2018.8593152

Sharma, V. S., Mehra, R., Kaulgud, V., \& Podder, S. (2018). An immersive future for software engineering: avenues and approaches. In Proceedings of the 40th International Conference on Software Engineering: New Ideas and Emerging Results (pp. 105-108).

Shroff, P. K. (1995). Determinants of the returns-earnings correlation. Contemporary Accounting Research, 12(1), 41-55.

Singh, J. E., \& Shivaprasad, H. N. (2018). Behavioral Biases Affecting Investors' Investment Decision: A Review of Literature. Available at SSRN 3120503. Retrieved from https://ssrn.com/abstract=3120503

State of Polish Video Games Industry 2017. (2017). Retrieved from http://polishgamers.com/upload/raport_A4_EN_2017_web.pdf

Stooq .pl[Accessed 31.03.2015]. Available from Internet: https://stooq.pl/

Throsby, D. (2008). The concentric circles model of the cultural industries. Cultural Trends, 17(3), 147-164.

Torchała, A. (2017). Jak wycenić akcje producenta gier? Retrieved from https://www.bankier.pl/wiadomosc/Jakwycenic-akcje-producenta-gier-7523520.html

UNCTAD. (2010). Creative Economy Report 2010. Retrieved from https://unctad.org/en/Docs/ditctab20103_en.pdf

UNCTAD. (2018). Creative Economy Outlook: Trends in international trade in creative industries. Retrieved from https://unctad.org/en/PublicationsLibrary/ditcted2018d3_en.pdf

Wijman, T. (2018). Mobile Revenues Account for More Than 50\% of the Global Games Market as It Reaches $\$ 137.9$ Billion in 2018. Retrieved March 25, 2019, from https://newzoo.com/insights/articles/global-gamesmarket-reaches-137-9-billion-in-2018-mobile-games-take-half/

Wyatt, A., \& Abernethy, M. (2008). Accounting for intangible investments. Australian Accounting Review, 18(2), 95-107. 